\title{
Analysis of Household Food Security Based on the Proportion of Food Expenditures and Energy Consumption in Flood-prone Areas in Wajo District
}

\author{
Syamsuar Manyullei ${ }^{1}$, Andi Imam Arundhana ${ }^{2 *}$ \\ ${ }^{1}$ Department of Environmental Health, Faculty of Public Health, Hasanuddin University, Makassar, Indonesia; ${ }^{2}$ Department of \\ Nutrition, Faculty of Public Health, Hasanuddin University, Makassar, Indonesia
}

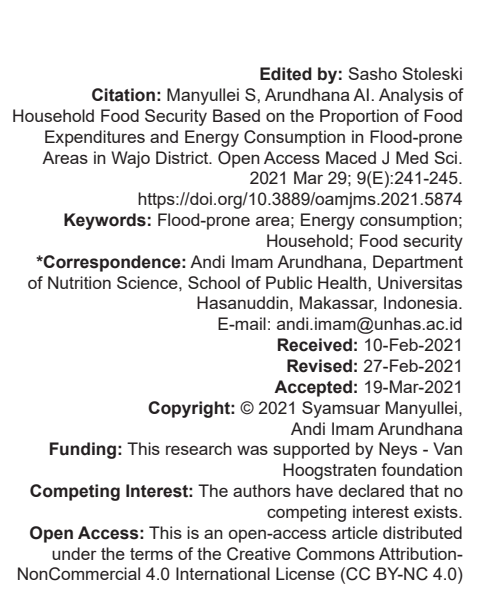

Abstract

BACKGROUND: Floods that inundate almost all areas in Wajo district caused difficulties for people in this district to access their daily needs, especially for foods as the distribution was inhibited. This situation was exacerbated as the food price increased leading to a greater risk of food insecurity of the household in this area.

AIM: The current study aimed to determine food security in flood-prone areas in Wajo District.

METHODS: This study was a cross-sectional conducted in the three subdistricts in Wajo Regency. The study was conducted from March to May the year 2018. A total of 304 study participants were involved in this study. The data have been collected using the developed questionnaire and observation sheet. All data analyses were performed using SPSS.

RESULTS: The result of the study shows that 139 households (46\%) included in this study were in the condition of lack of food and 165 households (54\%) were food insecure. Households with food-resistant and food vulnerable status were not found in the study area.

CONCLUSION: Therefore, households with food insecurity should manage their income by considering providing nutritious foods based on their income situation.

\section{Introduction}

Indonesia has achieved the first Millennium Development Goals, which is to halve the percentage of people living in hunger and extreme poverty [1]. However, issues of nutrition and stunting are still top priorities in the national development goals in the 2015-2019 [2] National Medium-Term Development Plan/RPJMN. Food security in Indonesia is still far behind and has not progressed, especially the problem of low levels of nutritional adequacy and the problem of stunting. The issue of malnutrition is still a barrier to Indonesia's potential [3].

The fulfillment of food is a human right that must be achieved because it has a key role in the development of the nation [4]. In the Indonesian Law Number 18 the year 2012, food security is defined as a condition of the fulfillment of food for the state to individuals, reflecting sufficient food (quantity and quality), safe, diverse, nutritious, equitable, and affordable. It does not conflict with the religion, belief, and culture of the community. Food security enables people to live healthy, active, and productive sustainably.
According to the Food and Agriculture Organization of the United Nations (FAO), food security consists of four dimensions, namely; food availability, accessibility, utilization, and stability. Food accessibility is a measure of the ability to obtain/secure food, usually determined by food affordability and money spent on food. In contrast, food availability is determined by the adequacy of food produced, stored, processed, distributed, and exchanged. In addition, dietary utilization refers to the essential nutrients obtained from the food consumed, including access to drinking water and food safety. It should reduce the risk of adverse effects in the other three dimensions [5]. Based on this description, it is known that food expenditure and energy consumption affect the level of food security.

Food expenditure can be determined based on the family income. If income increases, consumption patterns may be more diverse and nutritious [6]. Conversely, when the income is limited, the household will prioritize the food consumption of the family members, despite lack of nutrients of the food selected. Thus, it will take a large proportion of income to buy food [7]. Wajo is one of the areas in South Sulawesi that has low food expenditure. Based on BPS data for 2017 
on the food needs of the Wajo community, it shows that $54.26 \%$ is spent on food needs, and $45.74 \%$ is spent on non-food needs [8].

Meanwhile, the standard measurement of nutritional status is based on the Recommended Dietary Allowance (RDA) based on the average per capita daily energy consumption according to the table of nutritional adequacy figures by the Regulation of the Minister of Health of the Republic of Indonesia Number 75 of 2013, which is $2150 \mathrm{kcal}$. The development of the level of calorie intake in Indonesia each year has fluctuated, as shown in Figure 1. However, Indonesia's daily calorie consumption is still relatively low [9].

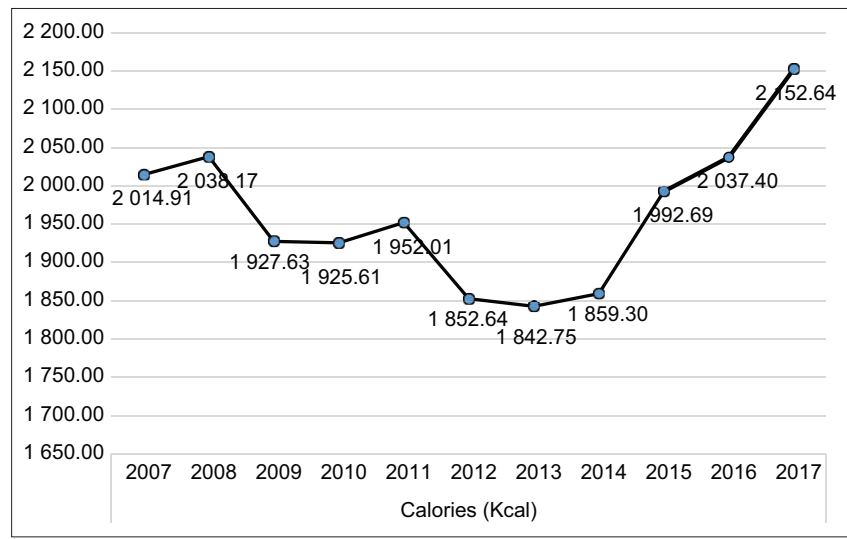

Figure 1: Indonesian Society's Daily Per Capita Calorie Consumption 2007-2017 (the data from Indonesia Statistical Center Body year 2017)

In addition to expenditure and food consumption patterns, floods also affect the level of food security in Wajo. In Wajo Regency, there is Lake Tempe which is the second largest lake on the island of Sulawesi, and if there is heavy rain, the lake water overflows and causes flooding [10].

In its report, FAO explains that flooding is one of the highest causes of damage and losses in the agricultural sector. Floods erode the topsoil, which is the main growing area for crops. From 2006 to 2016, nearly two-thirds of all damage and loss to crops was caused by flooding [11]. In addition, climate change also affects crop productivity and affects food availability. Access to and use of food will be affected indirectly through the effects of household, and individual income and utility of food can be impaired by loss of access to drinking water and damage to health [12].

Every year, several areas in Wajo suffer from floods. In 2016, floods in Wajo submerged 24 villages in five subdistricts such as Tanasitolo, Belawa, Tempe, Pammana, and Sabbangparu. Even in 2014, the flood inundated four villages for 1 month. During that time, the flood levels continued to fluctuate. This water level comes from the overflowing of Lake Tempe and the Walenae River [13].

Floods that inundated almost all areas in Wajo district made it difficult for residents to access various daily needs, especially access to foodstuffs. Floods hamper food distribution. Thus, the availability of food decreases and triggers an increase in prices. This study aims to determine the level of household food security based on the proportion of food expenditure and the level of energy consumption in flood-prone areas in Wajo Regency.

\section{Materials and Methods}

This study uses a quantitative approach with cross-sectional analysis techniques. The study was conducted in Wajo district in three districts, namely, Tempe, Tanasitolo, and Belawa districts. The sample was determined using the Lemeshow formula as much as 278 as the minimum sample. Then, in this study, the number of samples taken was 304 samples with a random sampling system technique. Data were collected using questionnaires and direct observation.

The data analysis method used was a descriptive statistical analysis in the form of cross-tabulations. This analysis is used to describe food security variables. Food security analysis is conducted to determine the status of household food security. The level of food security is measured by cross-classification indicators between food expenditure and energy adequacy [14].

Food expenditure measures food security from the economic aspect, while the fulfillment of food consumption adequacy in energy unit measures food security from the nutritional aspect [15]. The level of food security based on these indicators is grouped into four categories, namely, (1) food security: Proportion of food expenditure $(\leq 60 \%)$, sufficient consumption $(>80 \%$ energy adequacy); (2) food vulnerability: Proportion of food expenditure $(>60 \%)$, sufficient consumption $(>80 \%$ energy adequacy); (3) food deficiency: Proportion of food expenditure $(\leq 60 \%)$, underconsumption ( $\leq 80 \%$ Nutritional Adequacy Rate/RDA); and (4) food insecurity: Proportion of food expenditure (>60\%), underconsumption ( $\leq 80 \%$ energy sufficiency) [16].

\section{Results}

\section{Body mass index (BMI) indicators}

Respondents have varying BMI. The distribution of the respondents' BMI categories is presented in Table 1, as follows:

Based on Table 1, it is known that most of the respondents have a BMI of the normal category of $135(44.41 \%)$. There are $84(27.63 \%)$ of respondents with overweight category, $72(23.66 \%)$ obese, and only $13(4.25 \%)$ with underweight category. 
Table 1: Frequency distribution of BMI categories in Wajo Regency in 2018

\begin{tabular}{|c|c|c|c|c|c|c|c|c|}
\hline \multirow[t]{3}{*}{ Sex } & \multicolumn{8}{|c|}{ BMI categories } \\
\hline & \multicolumn{2}{|c|}{ Underweight } & \multicolumn{2}{|c|}{ Normal weight } & \multicolumn{2}{|c|}{ Overweight } & \multicolumn{2}{|c|}{ Obese } \\
\hline & $n$ & $\%$ & $\mathrm{n}$ & $\%$ & $\mathrm{n}$ & $\%$ & $n$ & $\%$ \\
\hline Male & 7 & 2.28 & 49 & 16.12 & 6 & 1.97 & 7 & 2.28 \\
\hline Female & 6 & 1.97 & 86 & 28.29 & 78 & 25.66 & 65 & 21.38 \\
\hline Jumlah & 13 & 4.25 & 135 & 44.41 & 84 & 27.63 & 72 & 23.66 \\
\hline
\end{tabular}

\section{Food Expenditure}

Household expenditure is the money spent by a family for their daily needs, including food expenditure. The level of food expenditure can be divided into two criteria, high and low levels of food expenditure. Households with high food expenditure show a relatively lower level of welfare compared to households with a low proportion of expenditure on food. The higher the food expenditure, the less prosperous the household is concerned. Conversely, the smaller the food expenditure, the more profitable the household is. The higher the food expenditure, the less prosperous the household involved. Conversely, the smaller the food expenditure, the more prosperous the household is.

The household expenses refer to the costs incurred for the consumption of all household members. Household consumption is classified into two, namely, food consumption and non-food consumption. Based on Table 2, it is known that 139 households $(45.7 \%)$ have low food expenditure, and 165 households (54.3\%) have high food expenditure. Henceforth, this category is included in determining the level of food security in flood-prone areas of Wajo Regency.

Table 2: Distribution of food expenditure in Wajo Regency in 2018

\begin{tabular}{llll}
\hline Food expenditure & Category & Number & $\%$ \\
\hline$<60 \%$ & Low & 165 & 54.3 \\
$\geq 60 \%$ & High & 139 & 45.7 \\
& Total & 304 & 100 \\
\hline
\end{tabular}

\section{Energy consumption level (ECL)}

The ECL is a reflection of the quality and quantity of food consumed by individuals or households. The staple food is usually a source of carbohydrates as well as a source of energy. The National Widyakarya on Food and Nutrition (WNPG) X in 2012 recommended the minimum requirement for a person to live a decent and healthy life is $2400 \mathrm{kcal} /$ day.

Adequate $\mathrm{ECL}$ of the households is divided into four criteria, including good, medium, low, and deficit level. In Table 3, 24 households (7.9\%) have good ECL level, 25 households (8.2\%) with medium, 56 households (18.4\%) with low, and 199 households $(65.5 \%)$ with deficit level. For the calculation of food security, the level of energy consumption that is more than $80 \%$ is in the sufficient category and for the level of energy consumption that is $<80 \%$ is in a low category.
Table 3: Distribution of household ECL categories in Wajo Regency in 2018

\begin{tabular}{llll}
\hline Energy consumption level & Category & Energy & \\
\cline { 3 - 4 } & & HH number & $\%$ \\
\hline$\geq 100 \%$ & Good & 24 & 7.9 \\
$80-99 \%$ & Medium & 25 & 8.2 \\
$70-80 \%$ & Low & 56 & 18.4 \\
$<70 \%$ & Deficit & 199 & 65.5 \\
& Total & 304 & 100 \\
\hline ECL: Energy consumption level. & & &
\end{tabular}

\section{Food security}

The components used to determine household food security can be seen from the proportion of food expenditure and energy consumption. In Table 4, the number of households is calculated by cross-tabulation between food expenditure and ECLs. The number of food resistant households is 127 households $(41.8 \%)$, 100 households $(32.9 \%)$ with food insecurity status, 38 households $(12.5 \%)$ with food deficiency status, and 39 households $(12.8 \%)$ are food insecure.

Table 4: Distribution of household food security in Wajo Regency in 2018

\begin{tabular}{|c|c|c|c|c|}
\hline Food security category & $\begin{array}{l}\text { The proportion } \\
\text { of food exp. (\%) }\end{array}$ & $\mathrm{ECL}(\%)$ & $\begin{array}{l}\text { Household } \\
\text { number }\end{array}$ & $\%$ \\
\hline $\begin{array}{l}\text { Food resistant, if the proportion of } \\
\text { food expenditure is low }(<60 \%) \text {, } \\
E C L \text { is enough }(>80 \%)\end{array}$ & 54.3 & 16.1 & 127 & 41.8 \\
\hline $\begin{array}{l}\text { Food vulnerable, if the } \\
\text { proportion of food expenditure } \\
\text { is high ( } \geq 60 \%) \text {, ECL is } \\
\text { enough }(>80 \%)\end{array}$ & 45.7 & 16.1 & 100 & 32.9 \\
\hline $\begin{array}{l}\text { Food deficient, if the proportion of } \\
\text { food expenditure is low }(<60 \%) \text {, } \\
\text { ECL is less }(\leq 80 \%)\end{array}$ & 54.3 & 83.9 & 38 & 12.5 \\
\hline $\begin{array}{l}\text { Insecure food, if the proportion of } \\
\text { food expenditure is high }(\geq 60 \%) \text {, } \\
E C L \text { is less }(\leq 80 \%)\end{array}$ & 45.7 & 83.9 & 39 & 12.8 \\
\hline Total & & & 304 & 100 \\
\hline
\end{tabular}

\section{Discussion}

\section{$B M I$ indicator}

The BMI indicator is the best indicator to measure the nutritional status of adults describing the state of the past and the present of nutritional status. In a normal circumstance, the development of body weight will be in line with the growth of height at a certain rate [17]. Based on the results of the study, it is known that only $13(4.25 \%)$ have a BMI in the underweight category. This can affect the energy consumption of respondents.

\section{Food expenditure}

Based on the study findings, it is known that 139 households $(45.7 \%)$ have low food expenditure and 165 (54.3\%) have high food expenditure. Low food expenditure is influenced by income. Increased income will result in individuals tending to increase the quality 
of food consumption. At lower income levels, food demand is prioritized on grains. If income increases, food consumption patterns will be more diverse, and in general, there will be an increase in food consumption with higher nutritional value [18]. Income will affect the pattern and level of household spending. A household will allocate its income for food, after that other needs. If the income earned is not sufficient to buy food, then the risk of becoming food insecure becomes even higher [19]. An increase in the income level will cause a change in the composition of the food consumed. However, more expenditure on food does not guarantee greater diversity in food consumption. Sometimes, the major shift in food habits is that the food consumed is more expensive [20].

\section{$E C L$}

Based on the results of the analysis, it is known that 24 households $(7.9 \%)$ have good ECL, 25 households $(8.2 \%)$ are less, 56 households (18.4\%) are moderate, and 199 households (65.5\%) deficit. This may be occurred due to low household consumption, especially in energy consumption. This is in line with the research that the nutritional status of a person is influenced by the intake of food consumed, which is determined by the ability to supply and manage consumption in each household [21]. The achievement of household food security can be seen from the adequacy of energy consumption derived from the pattern of household food consumption habits [22].

\section{Food security}

Table 3 shows that 127 households (41.8\%) are food resistant, 100 households (32.9\%) are food vulnerable, 38 households (12.5\%) are food deficient, and 39 households $(12.8 \%)$ have a food insecurity status. Food-resistant households mean households with a low food expenditure and good energy consumption. Households in this category do not have problems meeting their food needs. Meanwhile, households with food insecurity status and food insecurity have high food expenditure. High food expenditure means that more than $60 \%$ of the income is spent on food. This condition indicates the low income received by this household group. The low income they have causes the allocation for food expenditure to be unable to meet energy sufficiency. The family income is a critical factor that determines a household to achieve food security. The increased income is expected to make this household group achieve food security.

Households with food deficient and food insecurity, both have low levels of energy consumption. This is due to the relatively low quality of food and the less diverse consumption patterns. Food availability and affordability do not always guarantee its nutritional quality, the core components of food security include the use of nutrients that reflect the quality of food for an active and healthy lifestyle and refer to household use of food and the ability of individuals to absorb and metabolize nutrients [4], [23]. In addition, public awareness of the need for good and diverse food quality also plays a key role in fulfilling nutrition [24]. Even though the study participants have a high income, without knowledge of balanced nutrition, it tends to make the respondent modest in preparing consumption for their household [25]. Therefore, nutritional knowledge is an essential factor that determines households to achieve food security.

Many factors affect the increase of food demands. Besides the increase of population in the world, changes in food production and climate change which occurred in the past 40 years also contributed to the people's food needs. Therefore, it takes the right strategy and achieving food security [26]. One approach in overcoming food security is to do something sustainable, namely, by reducing waste, disposing of food, improving policy systems, and increasing food production. In addition, the strategy includes land use, animal control, and improved community nutrition [27].

\section{Conclusion and Suggestion}

The household food security condition based on the proportion of food expenditure and energy consumption in Wajo Regency is $41.8 \%$ food resistance, $32.9 \%$ food insecurity, $12.5 \%$ food deficient, and $12.8 \%$ food insecurity.

Food vulnerable households are recommended to increase family income. Meanwhile, for households with food deficiency, it is recommended to adjust the food menu to be more varied and highly nutritious. For food-insecure households, it is recommended that they increase family income and consume more highly nutritious food. Improving the quality of food can be improved by taking into account the quantity and quality of the food itself.

\section{References}

1. BAPPENAS. Laporan Pencapaian Tujuan Pembangunan Milenium Di Indonesia 2014. Jakarta: Badan Perencanaan Pembangunan Nasional; 2015.

2. BAPPENAS. Rencana Pembangunan Jangka Menengah Nasional (RPJMN) 2015-2019. Jakarta: Badan Perencanaan Pembangunan Nasional; 2014. https://doi.org/10.23917/jep. v7i2.3984

3. Dewan Ketahanan Pangan, Kementerian Pertanian dan World Food Programme. Food Security and Vulnerability Atlas of Indonesia 2015. Jakarta: Dewan Ketahanan Pangan, 
Kementerian Pertanian and World Food Programme; 2015. https://doi.org/10.6066/jtip.2015.26.2.222

4. Suryana. 2014. Menuju Ketahanan Pangan Indonesia Berkelanjutan 2025: Tantangan dan Penanganannya. Forum. Penelit. Agro Ekon. 2014;32(2):123-35.

5. Thecla A, George K, Alice OO. Principal Component Analysis of The Effects of Flooding on Food Security in Agrarian Communities of South Eastern Nigeria. Kenya: International Journal of Hydrology; 2018. https://doi.org/10.15406/ ijh.2018.02.00070

6. Hernanda EN, Indriani Y, Kalsum U. Pendapatan dan Ketahanan Pangan Rumah Tangga Petani Pada di Desa Rawan Pangan. Lampung: Universitas Lampung; 2017. https://doi.org/10.25182/ jgp.2008.3.3.172-179

7. BPS. Pengeluaran untuk Konsumsi Penduduk Indonesia Available from: http://www.bps.go.id/linkTable\%19Dinamis/ view/id/800. [Last accessed on 2018 Aug 25].

8. BPS. Pengeluaran Penduduk per Kapita. Diakses 17 Agustus. BPS; 2018.

9. BPS. Rata-rata Konsumsi Kalori dan Protein per Kapita per Hari Menurut Provinsi, 2007-2017. Available from: https://www. bps.go.id/statictable/2014/09/08/951/rata-rata-konsumsi-kaloridan-protein-per-kapita-per-hari-menurut-provinsi-2007-2017. html. https://doi.org/10.15642/mantik.2018.4.2.128-136 [Last accessed on 2018 Sep 2]

10. Paranda CT, Rauf S, Adisasmitha SA. Dampak Banjir Terhadap Infrastruktur di Kabupaten Wajo Berbasis Citra Landsat 8 dan Modis NRT (Near Real Time). Makassar: Universitas Hasanuddin; 2017.

11. Food and Agriculture Organizatio. The Impact of Disasters and Crises on Agriculture and Food Security. Italy, Rome: Food and Agriculture Organizatio; 2018.

12. Wheeler $\mathrm{T}$, Von Braun J. Climate change impacts on global food security. Science. 2013;341(6145):508-13. https://doi. org/10.1126/science.1239402 PMid:23908229

13. Sengkang A. Sebulan Banjir Wajo. Ekonomi Warga Lumpuh; 2014.

14. Maxwell $S$ and Frankenberger T. Household Food Security: Concept, Indicators, Measurements. A technical review. 1992.

15. Saliem P, Ariningsih E. Perubahan Konsumsi dan Pengeluaran Rumah Tangga di Pedesaan: Analisis Data SUSENAS 1999-2005. Bogor: Pusat Analisis Sosial Ekonomi dan Kebijakan Pertanian; 2008. https://doi.org/10.21082/akp. v16n2.2018.147-163

16. BPS. Buku 2: Konsumsi Kalori dan Protein Penduduk Indonesia dan Provinsi Edisi September BPS. Jakarta: BPS; 2013.

17. Anonim. Riset Kesehatan Dasar (RISKESDAS). Badan Penelitian dan Pengembangan Kesehatan Jakarta, Anonim: Direktorat Jenderal Bina Gizi dan KIA Kementerian Kesehatan RI; 2013. https://doi.org/10.22236/jmbp.v1i1.5708

18. Yudaningrum A. Analisis Hubungan Proporsi Pengeluaran dan Konsumsi Pangan Dengan Ketahanan Pangan Rumah Tangga Petani di Kabupaten Kulon Progo [Tesis]. Surakarta: Universitas Sebelas Maret; 2011. https://doi.org/10.20527/jpg. v5i2.5272

19. Dewi W. Analisis Ketahanan Pangan Tingkat Rumah Tangga di Kabupaten Bantul [Disertasi]. Yogyakarta: Universitas Gadjah Mada; 2011. https://doi.org/10.21776/ub.jepa.2019.003.02.2

20. Meitasari D. Analisis Determinan Keragaman Konsumsi Pangan Pada Keluarga Nelayan [Tesis]. Bogor: Institut Pertanian Bogor; 2008. https://doi.org/10.6066/jtip.2016.27.1.10

21. Suryana A. Ketahanan Pangan di Indonesia. Jakarta: Widyakarya Nasional Pangan dan Gizi; 2004.

22. Saputri R, Lestari LA, Susilo J. Pola Konsumsi dan Tingkat Ketahanan Pangan Rumah Tangga di Kabuaten Kampar Provinsi Riau. Yogyakarta: Universitas Gadjah Mada; 2016. https://doi.org/10.22146/ijen.23110

23. Soon JM, Tee ES. Changing trends in dietary pattern and implications to food and nutrition security in the association of South-East Asian Nations (ASEAN). Int J Nutr Food Sci. 2014;3(4):259-69. https://doi.org/10.11648/j.ijnfs.20140304.15

24. Mulyo J. Analisis Ketersediaan dan Pola Konsumsi 12. Pangan Masyarakat di Daerah Rawan Pangan. Yogyakarta: Universitas Gadjah Mada Bekerjasama dengan Badan Penelitian dan Pengembangan Pertanian; 2013. https://doi.org/10.6066/ jtip.2013.24.2.201

25. Amirudin MK. The Relationship between Parents' Income and Nutritional Status of Students in Tenggong Rejotangan 2 Primary School. J. Pendid Olahraga Kesehatan. 2014; 2(3): 564-8.

26. Godfray HC, Beddington JR, Crute IR, Haddad L, Lawrence D, Muir JF, et al. Food security: The challenge of feeding 9 billion people. Science. 2010;2020:1185383. https://doi.org/10.1126/ science. 1185383

27. Godfray HC, Garnett T. Food security and sustainable intensification. Phil Trans R Soc B. 2014;369(1639):20120273. https://doi.org/10.1098/rstb.2012.0273 